\title{
BMJ Global Health Rift valley fever: diagnostic challenges and investment needs for vaccine development
}

\author{
Velislava Petrova (D , ${ }^{1}$ Paul Kristiansen, ${ }^{2}$ Gunnstein Norheim, ${ }^{3}$ Solomon A Yimer $^{2}$
}

To cite: Petrova V, Kristiansen $P$, Norheim G, et al. Rift valley fever: diagnostic challenges and investment needs for vaccine development. BMJ Global Health 2020;5:e002694. doi:10.1136/ bmjgh-2020-002694

Handling editor Alberto L Garcia-Basteiro

Received 20 April 2020 Revised 15 June 2020 Accepted 24 June 2020

\section{Check for updates}

(C) Author(s) (or their employer(s)) 2020. Re-use permitted under CC BY-NC. No commercial re-use. See rights and permissions. Published by BMJ.

${ }^{1}$ Human Genetics Programme, Wellcome Sanger Institute, Cambridge, UK

${ }^{2}$ Vaccine Research and Development, Coalition for Epidemic Preparedness Innovations, Oslo, Norway ${ }^{3}$ Infectious Diseases, Vaccibody AS, Oslo, Norway

\section{Correspondence to}

Dr Velislava Petrova; velislava.petrova@cepi.net and Dr Solomon A Yimer; solomon.yimer@cepi.net

\section{ABSTRACT}

Rift valley fever virus (RVFV) is a causative agent of a viral zoonosis that constitutes a major clinical burden in wild and domestic ruminants. The virus causes major outbreaks in livestock (sheep, goats, cattle and camels) and can be transmitted to humans by contaminated animal products or via arthropod vectors. Human-to-human transmission has not been reported to date, but spill-over events from animals have led to outbreaks in humans in Africa and the Arabian Peninsula. Currently, there is no licensed human vaccine against RVFV and the virus is listed as a priority pathogen by the World Health Organisation (WHO) due to the high epidemic potential and the lack of effective countermeasures. Multiple large RVFV outbreaks have been reported since the virus was discovered. During the last two decades, over 4000 cases and $~ 1000$ deaths have been reported. The lack of systematic surveillance to estimate the true burden and incidence of human RVF disease is a challenge for planning future vaccine efficacy evaluation. This creates a need for robust diagnostic methodologies that can be deployed in remote regions to aid case confirmation, assessment of seroprevalence as well as pathogen surveillance required for the different stages of vaccine evaluation. Here, we perform comprehensive landscaping of the available diagnostic solutions for detection of RVFV in humans. Based on the identified gaps in the currently available in-house and commercially available methods, we highlight the specific investment needs for diagnostics that are critical for accelerating the development of effective vaccines against RVFV.

\section{INTRODUCTION}

Rift valley fever (RVF) is a disease caused by RVF virus (RVFV), an arbovirus member of the order Bunyavirales which can cause infections in a range of wild and domestic ruminants, as well as in humans. Humans are typically infected due to contact with infected animal products or via the bite of infected mosquito vectors. ${ }^{1}$ The first reported RVF outbreak was in 1931 in a sheep farm in Kenya ${ }^{2}$ and since then the virus has been a cause of multiple outbreaks in livestock leading to substantial number of deaths of domestic ruminants and consecutive negative health and economic

\section{Summary box}

Rift valley fever virus (RVFV) causes major outbreaks in livestock and can be transmitted to humans by contaminated animal products or via arthropod vectors.

- RVFV is listed as a priority pathogen by WHO due to its high epidemic potential and the lack of a licensed human vaccine or other effective countermeasures.

- Despite the wide range of commercial and in-house developed diagnostic methods available, there is limited validation data for performance of different tests, particularly for human samples.

- There is a need for validated tests that can be deployed in remote regions to aid case confirmation assessment of seroprevalence as well as pathogen surveillance required for the different stages of vaccine evaluation.

- There is a need for One Health approach to RVF disease management as well as local capacity strengthening to perform RVFV diagnostics in endemic regions to ensure early outbreak detection, case management and preparedness for future vaccine evaluation.

impact on humans. Although human-tohuman transmission has not been observed, the virus has caused several major outbreaks in humans in Africa (Republic of South Africa, Madagascar, Sudan) and Arabian Peninsula (Saudi Arabia, Yemen) $^{3-5}$ (table 1).

A large number of detected cases in humans is usually preceded by an outbreak in animals; detected or not. Despite the sporadic nature of outbreaks in humans and the limited antigenic diversity of the virus with the presence of a single serotype, ${ }^{6} \mathrm{RVFV}$ is listed as one of the priority pathogens in WHO Blueprint list due to its epidemic potential and lack of effective countermeasures. RVFV is also considered a select agent by the Centers for Disease Control and Prevention (CDC) and US Department of Agriculture. The epidemic potential of the virus is largely driven by the global presence of competent arthropod 


\begin{tabular}{llcc}
\hline $\begin{array}{l}\text { Table } 1 \\
2000\end{array}$ & \multicolumn{3}{l}{ Ten largest outbreaks of RVF in humans since year } \\
\hline Year & Location & $\begin{array}{l}\text { No of } \\
\text { cases }\end{array}$ & $\begin{array}{l}\text { No of } \\
\text { fatalities }\end{array}$ \\
\hline 2000 & Yemen & 1087 & 121 \\
\hline 2007 & Sudan & 738 & 230 \\
\hline 2006 & Kenya & 684 & 234 \\
\hline 2000 & Saudi Arabia & 516 & 87 \\
\hline 2006 & Tanzania & 264 & 109 \\
\hline 2010 & Republic of South Africa & 237 & 26 \\
\hline 2008 & Madagascar & 236 & 7 \\
\hline 2003 & Egypt & 148 & 27 \\
\hline 2006 & Somalia & 114 & 51 \\
\hline 2016 & Republic of Niger & 105 & 28 \\
\hline
\end{tabular}

Source: WHO reported data: https://www.who.int/news-room/factsheets/detail/rift-valley-fever

RVF, rift valley fever.

vectors ${ }^{78}$ and the active international travel and trade of livestock which increase the potential of the virus to cause infections outside endemic regions.

In this analysis article, we present a comprehensive landscaping of the diagnostic solutions available for RVFV detection in humans, highlight key gaps and challenges for specific diagnostic use cases and outline the development areas that require stronger focus to facilitate RVFV vaccine development.

\section{CLINICAL PRESENTATION AND DISEASE MANAGEMENT OF RVF}

RVFV carries a tripartite negative ssRNA genome containing $\mathrm{L}, \mathrm{M}$ and $\mathrm{S}$ genomic segments. The $\mathrm{N}$ and NS proteins are encoded by the S segment and the nonstructural NS protein is the main virulence determinant driving virus escape from the innate immune response. ${ }^{910}$ The incubation period for human RVF disease is 3-6 davs, and the disease in most cases presents in a flu-like febrile disease which is self-limiting. The early-disease symptoms are non-specific which likely leads to a large number of undetected cases. Less than $2 \%$ of cases develop severe disease with highly variable case fatality ratio ${ }^{11}$ (average $0.5 \%-2 \%$, but up to $28 \%$ in specific endemic regions) ${ }^{12}$ and characterised with ocular disease, hepatitis and/ or meningoencephalitis. ${ }^{13}$ Acute infection with RVFV during pregnancy has been linked to increased chance of miscarriage ${ }^{14}$ suggesting a possible additional disease burden in humans caused by vertical transmission. To better understand the impact of RVF, systematic longitudinal cohort studies on the interepidemic disease burden are warranted in the African region in particular.

Due to the lack of specific treatment available for RVF, the management of suspected cases is usually based on supportive therapy. According to CDC recommendations, the use of aspirin or non-steroid anti-inflammatory drugs in RVF cases should be avoided to reduce the risk of haemorrhagic complications. ${ }^{15}$ Severe cases are managed depending on the nature of the complications, with, for example, renal replacement therapy in patients with severe renal failure ${ }^{16}$ and artificial tear preparations and ophthalmic steroids in ocular disease cases. ${ }^{17}$ The use of ribavirin is recommended for prophylaxis and treatment of haemorrhagic fever caused by arenaviruses and other bunyaviruses ${ }^{18}$ but its efficacy for treatment of RVF has not been demonstrated. Other antiviral drugs (benzavir-2, favipiravir T-705) ${ }^{1920}$ as well as monoclonal antibodies against the virus ${ }^{21}$ are currently in development as RVF-specific treatment options, but they are yet to be evaluated and approved for clinical use.

Due to the lack of a licensed vaccine, prevention strategies for RVFV infection are limited to the use of personal protective equipment to prevent nosocomial infections ${ }^{22}$ as well as standard measures to prevent exposure to mosquito vectors (bed nets, long clothes).

\section{DIAGNOSTICS FOR RVFV DETECTION}

Due to the high containment level (biosafety level 3 (BSL3) ) required for handling of suspected RVF cases, diagnostic testing of RVFV is typically performed only in dedicated reference laboratories with trained biomedical staff. The limited laboratory capacity in endemic regions poses a major hurdle for timely diagnosis of RVF and leads to delays in outbreak detection. According to $\mathrm{WHO}$ recommendation, ${ }^{23}$ definitive diagnosis of RVFV infection requires: (1) detection of virus RNA in serum or plasma via real-time polymerase chain reaction (RT-PCR); (2) detection of anti-RVFV IgM and IgG antibodies; (3) detection of RVFV virus antigen and/ or (4) RVFV isolation. The selection of an optimal assay depends on the timing of sampling relative to disease progression and the ability to detect antigenic (isolated virus, viral RNA) or immunological markers (IgM and IgG). A combination of molecular and serological assays is usually needed to confirm RVFV cases if the timing of infection is unknown.

\section{Molecular tests}

Molecular tests are most useful during viremia (2-4 days post infection) ${ }^{24}$ and up to 8 days after onset of symptoms. ${ }^{25}$ Since viral load is correlated with disease severity, ${ }^{26}{ }^{27} \mathrm{qPCR}$ methods are often preferable to ensure simultaneous diagnosis and prognostic prediction. A number of commercial kits for molecular testing are currently available (table 2). They are primarily based on RT-PCR and enable the detection of RVFV as a single test or in a panel of several RNA viruses (Techne/Cole Palmer). The kits produced by LifeRiver and Altona are the only two CE-certified tests, while alternative methods are for research use only. Comparative tests of the commercially available kits across laboratories and different specimen preparation protocols have not yet been published to our knowledge. 
Table 2 In-house and commercially available molecular methods for RVFV detection in human samples

\begin{tabular}{|c|c|c|c|c|}
\hline \multicolumn{5}{|c|}{ In-house nucleic acid test (NAT) methods for RVFV detection } \\
\hline Method & Publication & Target gene & \multicolumn{2}{|l|}{ Description } \\
\hline $\begin{array}{l}\text { Real-time PCR (RT- } \\
\text { PCR) }\end{array}$ & Bird et al ${ }^{30}(2007)$ & $\mathrm{L}$ & \multicolumn{2}{|c|}{$\begin{array}{l}\text { Two-step assay for high-throughput detection of } 40 \text { known } \\
\text { strains. }\end{array}$} \\
\hline RT-PCR & Busquets et al. (2010) ${ }^{54}$ & $\mathrm{~L}$ & \multicolumn{2}{|l|}{ One-step real-time TaqMan assay. } \\
\hline RT-PCR & Drolet et al. (2012) ${ }^{24}$ & $\mathrm{~L}$ & \multicolumn{2}{|c|}{$\begin{array}{l}\text { Can be performed in BSL-2 as it involves pathogen } \\
\text { deactivation step. }\end{array}$} \\
\hline RT-PCR & Garcia et al. $(2001)^{55}$ & NSs & \multicolumn{2}{|l|}{ Two-step real-time TaqMan. } \\
\hline RT-PCR & Liu et al. $(2016)^{56}$ & $\mathrm{~L}$ & \multicolumn{2}{|c|}{$\begin{array}{l}\text { Developed as a TaqMan assay card for } 26 \text { pathogens. } \\
\text { Suitable for outbreak investigation or surveillance. }\end{array}$} \\
\hline RT-PCR & Mwaengo et al.(2012) & $L, S$ & \multicolumn{2}{|c|}{$\begin{array}{l}\text { Two-step real-time assay used for RVFV detection in } \\
\text { mosquitos. }\end{array}$} \\
\hline $\begin{array}{l}\text { Nested } \\
\text { RT-PCR }\end{array}$ & $\begin{array}{l}\text { Sanchez-Seco et } \\
\text { al.(2003) })^{59}\end{array}$ & S, L & \multicolumn{2}{|c|}{$\begin{array}{l}\text { Nested PCR assay, qualitative. Uses degenerate primers in } \\
\text { first round of PCR to capture all Phleboviruses. }\end{array}$} \\
\hline RT-PCR & Weidmann et al.(2008) 60 & $S$ & \multicolumn{2}{|l|}{ One-step assay, designed against 19 strains. } \\
\hline RT-PCR & Wilson et al.(2013) ${ }^{61}$ & L,M, NSs & \multicolumn{2}{|c|}{$\begin{array}{l}\text { Multiplex RT-PCR which detects } 3 \text { segments: } L \text { and } M \\
\text { segments as confirmatory targets, and NSs to differentiate } \\
\text { between infection and vaccination (suitable for DIVA testing). }\end{array}$} \\
\hline \multicolumn{5}{|c|}{ Commercially available NAT methods for RVFV detection } \\
\hline \multicolumn{3}{|l|}{ Method } & Manufacturer & Approval \\
\hline \multicolumn{3}{|c|}{ RealStar RVFV RT-PCR } & Altona & CE \\
\hline
\end{tabular}

BSL3, biosafety level 3; CE, approved for clinical testing; DIVA, distinguish infected from vaccinated individuals; EBOV, Ebola virus; FTD,

Fast-Track Diagnostics; qPCR, quantitative PCR; RUO, approved for research use only; RVFV, rift valley fever virus; YFV, yellow fever virus.

A range of in-house developed molecular methods are also available that use different protocols for detection of viral RNA. Unlike commercial methods, most of these in-house approaches have undergone some degree of external quality assessment (EQA). ${ }^{28} 29$ Two methods based on RT-PCR amplification (by Bird $e t a l^{30}$ and by Drosten $e t a l^{31}$ ) have been extensively tested across different laboratories and show high sensitivity, specificity and capacity for automation. The method of Bird $e t a l^{30}$ uses primers for the L segment of the RVFV genome and is suitable for high-throughput analysis as it can detect 40 RVFV strains at once. The protocol developed by Drosten et $a l^{31}$ targets the $\mathrm{M}$ segment and provides a better means for differential diagnosis as it offers a quantitative assay for detection of a panel of six viral haemorrhagic fever viruses including RVFV. In a comparative study of these two methods in 30 research laboratories across 16 countries, Escadafal et $a l,{ }^{29}$ showed these to be comparable and to perform with high sensitivity and specificity.

\section{Serological tests}

Serological assays enable the assessment of ongoing disease by presence of circulating antigen, or prior exposure to RVFV as demonstrated by presence of specific IgM and/or IgG antibodies. Serological tests based on ELISA are typically based on recombinant nucleocapsid protein (NP) and offer high specificity and simple sample processing. Diagnosis can also be made by immunofluorescent antibody (IFA) assay. Serological assays are key to epidemiological studies for identification of active infection or previous exposure to the virus. Active infection is conferred by detection of viral antigens, and previous exposure-by measuring virus specific IgM or IgG antibodies. Due to the short viremia, virus antigens are no 
Table 3 In-house and commercially available serological methods for RVFV detection in humans

\begin{tabular}{|c|c|c|c|}
\hline \multicolumn{4}{|c|}{ In-house serological methods for RVFV detection } \\
\hline Method & Publication & Target antibodies & Description \\
\hline ELISA (DIVA) & $\begin{array}{l}\text { McElroy et al. } \\
(2009)^{35}\end{array}$ & $\lg M$ or $\lg G$ & $\begin{array}{l}\text { Two parallel ELISAs which distinguish natural infections from } \\
\text { vaccinations (recombinant N and NSs proteins). Validated in goat and } \\
\text { human samples. Does not distinguish IgM versus IgG. }\end{array}$ \\
\hline ELISA & $\begin{array}{l}\text { Paweska et al. } \\
(2005)^{33}\end{array}$ & $\lg M$ and $\lg G$ & $\begin{array}{l}\text { IgG sandwich and IgM capture assays for humans made using } \\
\text { irradiated whole virus as antigen. Validated on human samples. }\end{array}$ \\
\hline ELISA & $\begin{array}{l}\text { Paweska et al. } \\
(2007)^{32}\end{array}$ & $\lg G$ & $\begin{array}{l}\text { IgG assay for humans, made using recombinant } \mathrm{N} \text { protein. Validated } \\
\text { on human samples. }\end{array}$ \\
\hline ELISA & $\begin{array}{l}\text { van Vuren Jansen } \\
\text { and Paweska } \\
(2009)^{33}\end{array}$ & $\lg M$ and $\lg G$ & $\begin{array}{l}\text { Separate IgG, IgM indirect ELISAs for humans and ruminants, which } \\
\text { uses recombinant N protein. }\end{array}$ \\
\hline ELISA & $\begin{array}{l}\text { van Vuren et al. } \\
(2009)^{33}\end{array}$ & $\lg M$ or $\lg G$ & $\begin{array}{l}\text { Sandwich ELISA for ruminants and humans. Does not distinguish } \\
\text { IgM versus IgG. Includes preincubation of samples at } 56 \mathrm{C} 1 \text { hour to } \\
\text { reduce biosafety requirements. }\end{array}$ \\
\hline VNT & $\begin{array}{l}\text { Winchger Schreur } \\
\text { et al. }(2017)^{62}\end{array}$ & $\begin{array}{l}\text { Any neutralising } \\
\text { antibodies }\end{array}$ & $\begin{array}{l}\text { Uses avirulent RVFV which expresses eGFP. Takes } 48 \text { hours and is } \\
\text { more sensitive than classic VNT. Not species-specific. }\end{array}$ \\
\hline OFIS & $\begin{array}{l}\text { Sobarzo et } \\
\text { al. }(2007)^{36}\end{array}$ & $\lg G$ & $\begin{array}{l}\text { Based on sandwich ELISA. Irradiated RVFV and control antigen are } \\
\text { immobilised on an optical fibre. More sensitive to low-levels of serum } \\
\text { IgG than standard ELISA. Tested on human samples. }\end{array}$ \\
\hline Luminex & $\begin{array}{l}\text { Van der Wal et } \\
\text { al.(2012) }\end{array}$ & $\lg M$ and $\lg G$ & $\begin{array}{l}\text { Bead-based assay for simultaneous detection of antibodies against } \\
\text { RVFV Gn and N proteins. Demonstrated utility for DIVA testing. }\end{array}$ \\
\hline Luminex & Wu et al. $(2014)^{38}$ & $\lg G$ & $\begin{array}{l}\text { Designed as a multipathogen assay for virus haemorrhagic fevers } \\
\text { including RVFV. No evaluation of diagnostic sensitivity for RVFV in } \\
\text { clinical samples. }\end{array}$ \\
\hline
\end{tabular}

eGFP, enhanced green fluorescent protein; OFIS, optical fiber immunosensor; VNT, virus neutralisation test.

Commercially available serological methods for RVFV detection

\begin{tabular}{lll}
\hline Method & Manufacturer & Approval \\
\hline IFA RVFV IIFT IgG & EUROIMMUN & CE \\
IFA RVFV IIFT IgM & EUROIMMUN & CE \\
ELISA RVFV IgM/IgG & Biological Diagnostic Supplies Limited & CE \\
ELISA RVFV IgM & ID-Vet & At development and validation stage. \\
\hline
\end{tabular}

CE, approved for clinical testing; DIVA, distinguish infected from vaccinated individuals; IFA, immunofluorescent antibody; IIFT, indirect immunofluorescence; RVFV, rift valley fever virus.

longer detectable after 4-5 days. Therefore, a reliable use of serological assays for RVF diagnosis should incorporate a combination of tests for detection of viral antigens and serum IgM. The majority of commercially available serological assays have been developed and approved for animal testing only. Two commercially available IFA assays for IgM and IgG (Euroimmun) are CE certified serological assays for humans, however, their performances have not been evaluated by external independent assessment (table 3). There are two commercial ELISA kits manufactured by Biological Diagnostic Supplies Limited (BDSL) and based on assays for detection of $\operatorname{IgM}$ and/or IgG antibodies in serological samples originally developed by Paweska et $a l,{ }^{32}$ and Jansen van Vuren et $a l .{ }^{33}$ An ELISA detecting anti-RVFV IgM is also currently in development by ID-Vet company but has not yet received CE certification for use in humans. The performance of BDSL and ID-Vet assays has been evaluated in animal serum samples as part of an European ring trail. This study shows high specificity and sensitivity of both assays and highlights their reliable use for serological testing. ${ }^{34}$ To our knowledge, similar assessment of commercial ELISA assays in human samples have not been performed to date.

In-house developed serological assays are typically based on recombinant RVFV NP or irradiated whole RVFV virions as a coating antigen for detection of $\mathrm{IgG}$ and IgM responses directed against the virus. Like molecular assays, ELISA-based methods have mainly been tested in ruminants and lack EQA in humans. The ability to distinguish infection from vaccination is essential for vaccine development. McElroy et $a l^{35}$ have developed a diagnostic assay that can distinguish infected from vaccinated individuals (DIVA) using an ELISA based on recombinant $\mathrm{N}$ and Ns proteins. The assay has been validated in humans but not yet tested by external independent assessment. In attempt to develop a serological assay that can be 


\begin{tabular}{|c|c|c|}
\hline Method & Publication & Description \\
\hline LAMP & Peyrefitte et al. (2008) ${ }^{63}$ & A 30 min qualitative assay. No independent EQA. \\
\hline LAMP & Le Roux et al. (2009) $)^{39}$ & A $30-45$ min real-time assay. One EQA study with sensitivity limitations. \\
\hline RPA-PCR & Eular et al. (2012) $)^{40}$ & $\begin{array}{l}\text { A qualitative assay with }<30 \text { min run time. Detection of a panel of } 10 \\
\text { biothreat pathogens. Optimal performance on EQA study in } 2012 \text {. }\end{array}$ \\
\hline Rapid nanogold assay & Zaher et al. (2018) ${ }^{41}$ & $\begin{array}{l}\text { Colorimetric assay based on unmodified gold nanoparticles which } \\
\text { detects unamplified RVFV RNA. Produces results in } 30 \text { min. Prototype } \\
\text { stage. No independent EQA. }\end{array}$ \\
\hline Pen-side test & Cêtre-Sossah et al. (2019) & $\begin{array}{l}\text { Chromatographic strip coated with antibodies against RVFV N protein. } \\
\text { Non-quantitative. No independent EQA. }\end{array}$ \\
\hline
\end{tabular}

EQA, external quality assessment; LAMP, loop-mediated isothermal amplification; RDTs, rapid diagnostic tests; RVFV, rift valley fever virus.

used in remote settings, Sobarzo et $a \hat{l}^{36}$ have developed an immunosensor technique for detection of RVFV IgG antibodies using antigen-coated optical fiber. Although the technique shows high sensitivity in human samples and has the potential to be adapted in a portable format, it has not been evaluated as an alternative to standard ELISA techniques.

While ELISA methods can detect serological responses to one antigen at a time, detection of RVFV-specific antibodies can be performed in a multiplex fashion using bead-based assays. Such assays are typically based on recombinant virus proteins conjugated to microbeads and enable simultaneous screening for antibodies against a number of viral proteins. ${ }^{37} 38$

\section{Rapid diagnostic tests}

Rapid diagnostic tests (RDTs) can play a key role in early detection of potential RVFV outbreaks, in particular in areas distant from laboratories, and can play a key role in future potential vaccine efficacy trials if their sensitivity and specificity is comparable to the 'goldstandard' RT-PCR. Several methods for rapid molecular testing have been developed using protocols based on isothermal amplification (loop-mediated isothermal amplification and RPA-PCR) (by Le Roux $e t a l^{39}$ and Euler $e t a l,{ }^{40}$ table 4 ). Both of these methods have under 45 min run time but there are no public data on how they perform compared with RT-PCR. As an alternative to amplification-based methods for detection of RVFV RNA, Zaher et $a l^{41}$ have developed a prototype of a colorimetric method for rapid identification of unamplified RNA with a detection limit of 10 RNA copies/reaction making rapid screening possible in settings with limited technical infrastructure. Further validation and development of this method beyond the prototype stage is still in progress. A report of a pen side veterinary test for diagnosis of RVF using chromatographic strips has also been published. ${ }^{42}$ This method uses gold-labelled monoclonal antibodies against RVFV N protein and has a detection limit of $10^{3}-10^{5} \mathrm{pfu}$ depending on the strain. This rapid test lacks quantitative results but could be used for firstline testing of livestock to detect early stages of suspected disease transmission, and serve as an early warning of potential subsequent human outbreaks.

\section{Sequencing}

Sequencing of the RVFV genome has been used to monitor virus epidemiological spread and geographic distribution of different strains. ${ }^{6}$ The ability to perform whole-genome sequencing on clinical specimens can aid the identification of new strains as well as the mapping of virus evolution and transmission. Despite the presence of a single serotype, there are 15 RVFV lineages identified ${ }^{43}$ and they show certain differences in virulence and pathogenicity in animal models, ${ }^{30} 44$ highlighting the importance of comprehensive genetic characterisation of RVFV for disease management as well. This genetic diversity of RVFV needs to be considered in the design of molecular diagnostic assays to ensure optimal assay sensitivity across all virus lineages. Recent advances in sequencing and comparative genomics for use in outbreak monitoring (eg, nextstrain.org) can further improve our understanding of transmission pathways.

\section{Challenges in RVF diagnosis}

Differential diagnosis of RVF is challenging due to the broad overlap of symptoms with other haemorrhagic fevers. Specimens from any suspected cases need to be handled under enhanced BSL-3 conditions and transferred under biological hazard regulations to a respective reference laboratory, requiring trained biomedical professionals. Despite the wide range of commercial and laboratory-developed methods, currently there is not a validated point-of-care diagnostic tool. The commercially available RT-PCR kits can be used for case confirmation, but the short period of viremia requires a combination of the molecular assay with a serological test to ensure reliable detection of cases. The lack of published independent studies evaluating any of the commercial molecular and ELISA assays for humans complicate the use of these tests for large-scale surveillance. Similarly, the quality of in-house methods requires further crossvalidation between laboratories to evaluate their applicability for wider use. The necessity for BSL-3 facilities and 
trained biomedical staff for handling of suspected RVFV samples is particularly challenging in remote areas, close to farms or animal slaughtering facilities where outbreaks are mostly likely to occur. The high overlap of disease symptomology with other febrile illnesses, as well as the need for use of reference laboratories for testing likely lead to underreporting of cases and ongoing virus transmission which eventually increases the epidemic risk associated with RVFV. Epidemiological studies in cohorts or areas with evidence of prior outbreaks are recommended to enable estimation if the true disease burden and validation of existing molecular and serological tests, including RDTs when available.

\section{IMPORTANCE OF DIAGNOSTICS FOR RVFV VACCINE DEVELOPMENT}

The low antigenic diversity with the presence of a single serotype make RVFV a good target for vaccine development. A large variety of RVFV vaccines for livestock have been developed but primarily used in endemic regions due to the lack of licence for global veterinary use. ${ }^{45-47}$ Currently, there are no licensed RVFV vaccines for human use and the understanding of the correlates of protection is limited (see in-depth reviews by Faburay $e t$ $a l,{ }^{48}$ Dungu $e t a l^{49}$ and Ikegami $\left.{ }^{50}\right)$. As of 2017, there are 15 vaccine candidates at preclinical development stage and two vaccines that have reached clinical development. ${ }^{51}$ The Coalition for Epidemic Preparedness Innovations is supporting development of several RVF vaccines for use in humans in its portfolio and has currently signed funding agreements with two vaccine awardees to develop a human vaccine against RVFV. The first agreement, worth US $\$ 12.5$ million is signed with Wageningen Bioveterinary Research in the Netherlands and will be used for vaccine manufacturing, preclinical research, and a phase I study to assess the safety, tolerability, and immunogenicity of a single-dose live attenuated vaccine candidate (RVFV-4s) against RVFV (https://www.larissa.online/about).

The second agreement, worth US\$9.5 million is with Colorado State University ${ }^{52}$ and will be used for manufacturing and preclinical studies to assess a single-dose live attenuated vaccine candidate (DDVax) against RVF. DDVax is a second generation RVF vaccine, which was developed after knocking out the main disease-causing genes from the RVFV genome.

Diagnostics play several key roles in facilitating vaccine development, from mapping of disease burden to case confirmation in efficacy trials. ${ }^{51} \mathrm{~A}$ WHO report ${ }^{53}$ following a consultation on 'RVF Vaccine and Treatment Evaluation' highlights the case confirmation by RT-PCR and IgM ELISA as a primary endpoint for vaccine development as well as the DIVA testing as secondary endpoint to determine infection status as a surrogate of protection. The report further recommends the adoption of a One Health approach for diagnostic surveillance as well as vaccine development due to the tight relationship between outbreaks in livestock and in humans.

In addition to efficacy estimation, the reliable estimation of disease incidence in the study area is important for the planning of sample size and feasibility of clinical efficacy trials and their enrolment criteria (figure 1). Conducting clinical trials for development of an RVFV

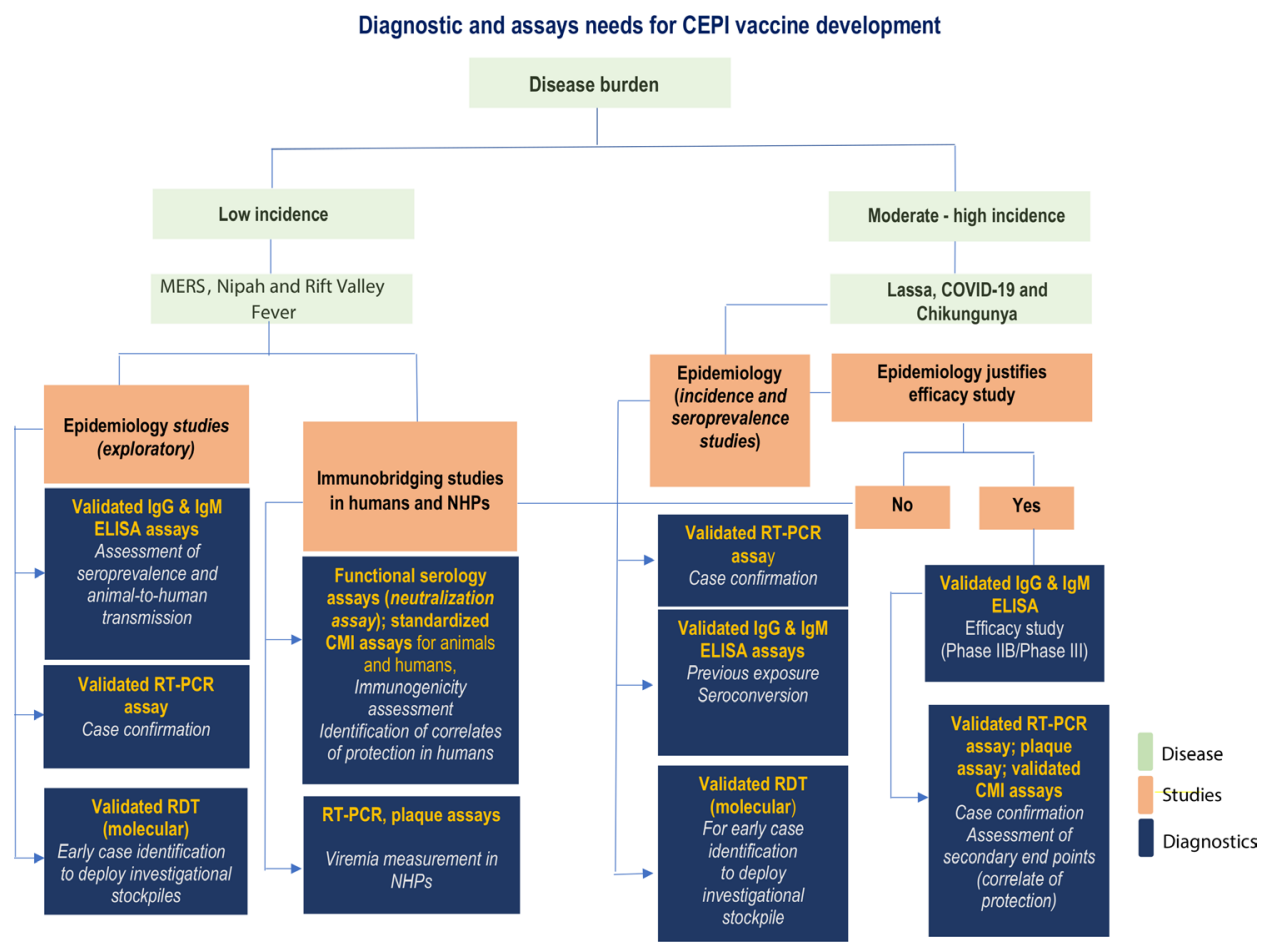

Figure 1 Outline of diagnostic needs for vaccine development defined by the Coalition for Epidemic Preparedness Innovations (CEPI). RDT, rapid diagnostic tests; RT-PCR, real-time PCR; MERS, Middle-Eastern respiratory virus: NHPs, nonhuman primates; CMI, cell-mediated immunity; 
vaccine is complicated by the sporadic nature of RVF outbreaks and their relatively short period of activity (3-7 months), which has an impact on logistical planning of such trials. Therefore, sufficient resources need to be spent on surveillance strengthening both in humans and in livestock (who are the main source of outbreaks in humans) to ensure early detection of infections before an outbreak has occurred. Since outbreaks often occur in remote areas, coordination of efforts among affected areas might be required to determine if the incidence is enabling the setup of a clinical trial likely to be conclusive on vaccine evaluation. To ensure a rapid trial setup with emerging outbreaks, reliable diagnostics need to be validated ahead of time and supported to ensure they have the necessary regulatory approvals for use in the affected countries to be readily deployed.

The validation of molecular and serological assays for RVFV is a stepping stone for the design of epidemiological and ecological studies necessary to estimate the global seroprevalence to RVFV and the spectrum of disease severity in endemic regions and the pattern of disease progression in high-risk groups.

\section{INVESTMENT NEEDS IN RVFV DIAGNOSTICS FOR ACCELERATING RVFV VACCINE DEVELOPMENT}

Based on the performed landscaping of diagnostic solutions for RVFV detection and the identified gaps in infrastructure and surveillance methods, we highlight several areas of research and investment needs that can be considered in future consultations to guide WHO recommendations for successful RVFV vaccine development:

a. Development of target product profile and validation protocols for evaluation of molecular and serological assays (including DIVA testing) for diagnosis of human RVFV.

b. Providing standards and sample panels to enable validation of diagnostic tests.

c. Development of RDTs to enable early detection of disease transmission in endemic regions and to facilitate future epidemiology studies.

d. Estimate incidence and seroprevalence of RVFV in areas and populations at particular risk, to prepare for potential future vaccine efficacy evaluation.

e. Undertake research to improve the understanding of underlying ecological factors for disease transmission.

f. Strengthening of surveillance systems in at risk areas and populationsthrough support of RVFV laboratory networks and sample transport systems, as well as through access to RDTs.

g. Improved RVF response protocols for differential diagnosis and early triaging of patients.

h. Estimate the societal and economic cost of the RVFV disease burden to evaluate the full public health value of access to a future human RVFV vaccine.

\section{CONCLUSION}

Despite its restricted prevalence in endemic regions in Africa and the Arabic Peninsula, RVFV is a pathogen with high epidemic potential due to the worldwide presence of competent arthropod vectors and the possibility of spill-over events from livestock subject to active international trade. In this context, the development of safe, effective and affordable vaccines for prevention of infection in animals and in humans is a priority. Robust and specific solutions for RVF diagnostics are required to determine seroprevalence, to perform case confirmation and to enable future vaccine efficacy evaluation. Diagnostics need to be easily deployable in areas with disease outbreaks and to provide a reliable measure to differentiate between previous exposure and vaccine-derived immunity. Despite the presence of established diagnostic tests developed to date, substantial efforts are recommended to validate these in field settings most affected by RVFV outbreaks. Due to the high containment level required for handling of suspected cases, local capacity strengthening and diagnostics is recommended to ensure early outbreak detection, case management, continuous pathogen surveillance, and readiness to enable future vaccine evaluation. Although this review focuses on mapping of diagnostic needs for RVFV sampling in humans, the management of RVFV disease should be performed in the context of the broader One Health paradigm. Therefore, any future strategies for RVFV vaccine development should incorporate combined efforts for human and animal prophylaxis to reduce disease prevalence in animals and mitigate the risk of recurrent human outbreaks.

Acknowledgements We acknowledge Carolyn Clark for her advice on the preparation of the paper and the review of the completed manuscript.

Contributors VP, SAY and GN defined the scope of the work. VP performed the analysis and wrote the manuscript. SAY, GN and PK provided comments on the manuscript and all authors contributed to the final revisions.

Funding This study was supported by Coalition for Epidemic Preparedness Innovations.

Competing interests None declared.

Patient consent for publication Not required.

Provenance and peer review Not commissioned; externally peer reviewed.

Data availability statement All data used for the publication is available in the respective references provided.

Open access This is an open access article distributed in accordance with the Creative Commons Attribution Non Commercial (CC BY-NC 4.0) license, which permits others to distribute, remix, adapt, build upon this work non-commercially, and license their derivative works on different terms, provided the original work is properly cited, appropriate credit is given, any changes made indicated, and the use is non-commercial. See: http://creativecommons.org/licenses/by-nc/4.0/.

ORCID iD

Velislava Petrova http://orcid.org/0000-0001-5997-0173

\section{REFERENCES}

1 Javelle E, Lesueur A, Pommier de Santi V, et al. The challenging management of Rift Valley fever in humans: literature review of the clinical disease and algorithm proposal. Ann Clin Microbiol Antimicrob 2020;19:4. 
2 Daubney RH., J. R, Garnham PC. Enzootic hepatitis or Rift Valley fever. An undescribed virus disease of sheep cattle and man from Aast Africa. The journal of Pathology and Bacteriology.

3 Wright D, Kortekaas J, Bowden TA, et al. Rift Valley fever: biology and epidemiology. J Gen Virol 2019;100:1187-99.

4 Madani TA, Al-Mazrou YY, Al-Jeffri MH, et al. Rift Valley fever epidemic in Saudi Arabia: epidemiological, clinical, and laboratory characteristics. Clin Infect Dis 2003;37:1084-92.

5 Lancelot R, Béral M, Rakotoharinome VM, et al. Drivers of Rift Valley fever epidemics in Madagascar. Proc Natl Acad Sci U S A 2017;114:938-43

6 Maluleke MR, Phosiwa M, van Schalkwyk A, et al. A comparative genome analysis of Rift Valley fever virus isolates from foci of the disease outbreak in South Africa in 2008-2010. PLoS Negl Trop Dis 2019;13:e0006576.

7 Golnar AJ, Kading RC, Hamer GL. Quantifying the potential pathways and locations of Rift Valley fever virus entry into the United States. Transbound Emerg Dis 2018;65:85-95.

8 Golnar AJ, Turell MJ, LaBeaud AD, et al. Predicting the mosquito species and vertebrate species involved in the theoretical transmission of Rift Valley fever virus in the United States. PLoS Negl Trop Dis 2014;8:e3163.

9 Bouloy M, Weber F. Molecular biology of Rift Valley fever virus. Open Virol J 2010:4:8-14.

10 Sall AA, Zanotto PM, Sene OK, et al. Genetic reassortment of Rift Valley fever virus in nature. J Virol 1999;73:8196-200.

11 Laughlin LW, Meegan JM, Strausbaugh LJ, et al. Epidemic Rift Valley fever in Egypt: observations of the spectrum of human illness. Trans $R$ Soc Trop Med Hyg 1979;73:630-3.

12 Mohamed M, Mosha F, Mghamba J, et al. Epidemiologic and clinica aspects of a Rift Valley fever outbreak in humans in Tanzania, 2007. Am J Trop Med Hyg 2010;83:22-7.

13 Nguku PM, Sharif SK, Mutonga D, et al. An investigation of a major outbreak of Rift Valley fever in Kenya: 2006-2007. Am J Trop Med Hyg 2010;83:05-13.

14 Baudin M, Jumaa AM, Jomma HJE, et al. Association of Rift Valley fever virus infection with miscarriage in Sudanese women: a crosssectional study. Lancet Glob Health 2016;4:e864-71.

15 CDC. Rift Valley fever. Available: <https://wwwnc.cdc.gov/travel/ diseases/rift-river-valley>

16 El Imam M, El Sabiq M, Omran M, et al. Acute renal failure associated with the Rift Valley fever: a single center study. Saudi J Kidney Dis Transpl 2009;20:1047-52.

17 Al-Hazmi A, Al-Rajhi AA, Abboud EB, et al. Ocular complications of Rift Valley fever outbreak in Saudi Arabia. Ophthalmology 2005;112:313-8.

18 Bossi P, Tegnell A, Baka A, et al. Bichat guidelines for the clinical management of haemorrhagic fever viruses and bioterrorism-related haemorrhagic fever viruses. Euro Surveill 2004;9:29-30.

19 Islam MK, Strand M, Saleeb M, et al. Anti-Rift Valley fever virus activity in vitro, pre-clinical pharmacokinetics and oral bioavailability of benzavir-2, a broad-acting antiviral compound. Sci Rep 2018;8:1925

20 Scharton D, Bailey KW, Vest Z, et al. Favipiravir (T-705) protects against peracute Rift Valley fever virus infection and reduces delayed-onset neurologic disease observed with ribavirin treatment. Antiviral Res 2014;104:84-92.

21 Allen ER, Krumm SA, Raghwani J, et al. A protective monoclonal antibody targets a site of vulnerability on the surface of Rift Valley fever virus. Cell Rep 2018;25:e3754:3750-8.

22 Al-Hamdan NA, Panackal AA, Al Bassam TH, et al. The risk of nosocomial transmission of Rift Valley fever. PLoS Negl Trop Dis 2015;9:e0004314.

23 WHO. Introduction to Rift Valley fever. managing infectious hazards.

24 Drolet BS, Weingartl HM, Jiang J, et al. Development and evaluation of one-step rRT-PCR and immunohistochemical methods for detection of Rift Valley fever virus in biosafety level 2 diagnostic laboratories. J Virol Methods 2012;179:373-82.

25 Tong C, Javelle E, Grard G, et al. Tracking Rift Valley fever: from Mali to Europe and other countries, 2016. Euro Surveill 2019;24.

26 Jansen van Vuren P, Shalekoff S, Grobbelaar AA, et al. Serum levels of inflammatory cytokines in Rift Valley fever patients are indicative of severe disease. Virol J 2015;12:159.

27 Njenga MK, Paweska J, Wanjala R, et al. Using a field quantitative real-time PCR test to rapidly identify highly viremic Rift Valley fever cases. J Clin Microbiol 2009;47:1166-71.

28 Monaco F, Cosseddu GM, Doumbia B, et al. First external quality assessment of molecular and serological detection of Rift Valley fever in the Western Mediterranean region. PLoS One 2015:10:e0142129.
29 Escadafal C, Paweska JT, Grobbelaar A, et al. International external quality assessment of molecular detection of Rift Valley fever virus. PLoS Negl Trop Dis 2013;7:e2244.

30 Bird BH, Khristova ML, Rollin PE, et al. Complete genome analysis of 33 ecologically and biologically diverse Rift Valley fever virus strains reveals widespread virus movement and low genetic diversity due to recent common ancestry. J Virol 2007;81:2805-16.

31 Drosten C, Göttig S, Schilling S, et al. Rapid detection and quantification of RNA of Ebola and Marburg viruses, Lassa virus, Crimean-Congo hemorrhagic fever virus, Rift Valley fever virus, dengue virus, and yellow fever virus by real-time reverse transcription-PCR. J Clin Microbiol 2002:40:2323-30.

32 Paweska JT, Smith SJ, Wright IM, et al. Indirect enzyme-linked immunosorbent assay for the detection of antibody against Rift Valley fever virus in domestic and wild ruminant sera. Onderstepoort $J$ Vet Res 2003;70:49-64.

33 Jansen van Vuren P, Paweska JT. Laboratory safe detection of nucleocapsid protein of Rift Valley fever virus in human and animal specimens by a sandwich ELISA. J Virol Methods 2009;157:15-24.

34 Kortekaas J, Kant J, Vloet $\mathrm{R}$, et al. European ring trial to evaluate ELISAs for the diagnosis of infection with Rift Valley fever virus. $J$ Virol Methods 2013;187:177-81.

35 McElroy AK, Albariño CG, Nichol ST. Development of a RVFV ELISA that can distinguish infected from vaccinated animals. Virol $J$ 2009;6:125

36 Sobarzo A, Paweska JT, Herrmann S, et al. Optical fiber immunosensor for the detection of IgG antibody to Rift Valley fever virus in humans. J Virol Methods 2007:146:327-34.

37 van der Wal FJ, Achterberg RP, de Boer SM, et al. Bead-Based suspension array for simultaneous detection of antibodies against the Rift Valley fever virus nucleocapsid and GN glycoprotein. J Virol Methods 2012;183:99-105.

38 Wu W, Zhang S, Qu J, et al. Simultaneous detection of IgG antibodies associated with viral hemorrhagic fever by a multiplexed Luminex-based immunoassay. Virus Res 2014;187:84-90.

39 Le Roux CA, Kubo T, Grobbelaar AA, et al. Development and evaluation of a real-time reverse transcription-loop-mediated isothermal amplification assay for rapid detection of Rift Valley fever virus in clinical specimens. J Clin Microbiol 2009;47:645-51.

40 Euler M, Wang Y, Nentwich O, et al. Recombinase polymerase amplification assay for rapid detection of Rift Valley fever virus. $J$ Clin Virol 2012;54:308-12.

41 Zaher MR, Ahmed HA, Hamada KEZ, et al. Colorimetric detection of unamplified Rift Valley fever virus genetic material using unmodified gold nanoparticles. Appl Biochem Biotechnol 2018;184:898-908.

42 Cêtre-Sossah C, Pédarrieu A, Juremalm M, et al. Development and validation of a pen side test for Rift Valley fever. PLoS Negl Trop Dis 2019;13:e0007700.

43 van Schalkwyk A, Romito M. Genomic characterization of Rift Valley fever virus, South Africa, 2018. Emerg Infect Dis 2019;25:1979-81.

44 Ikegami T, Balogh A, Nishiyama S, et al. Distinct virulence of Rift Valley fever phlebovirus strains from different genetic lineages in a mouse model. PLoS One 2017;12:e0189250.

45 Faburay B, Wilson WC, Gaudreault NN, et al. A recombinant Rift Valley fever virus glycoprotein subunit vaccine confers full protection against Rift Valley fever challenge in sheep. Sci Rep 2016;6:27719.

46 Spik K, Shurtleff A, McElroy AK, et al. Immunogenicity of combination DNA vaccines for Rift Valley fever virus, tick-borne encephalitis virus, Hantaan virus, and Crimean Congo hemorrhagic fever virus. Vaccine 2006:24:4657-66.

47 Dodd KA, Bird BH, Metcalfe MG, et al. Single-Dose immunization with virus replicon particles confers rapid robust protection against Rift Valley fever virus challenge. J Virol 2012;86:4204-12.

48 Faburay B, LaBeaud AD, McVey DS, et al. Current status of Rift Valley fever vaccine development. Vaccines 2017;5. doi:10.3390/ vaccines5030029. [Epub ahead of print: 1909 2017].

49 Dungu B, Lubisi BA, Ikegami T. Rift Valley fever vaccines: current and future needs. Curr Opin Virol 2018;29:8-15.

50 Ikegami T. Candidate vaccines for human Rift Valley fever. Expert Opin Biol Ther 2019;19:1333-42.

51 Gouglas D, Thanh Le T, Henderson K, et al. Estimating the cost of vaccine development against epidemic infectious diseases: a cost minimisation study. Lancet Glob Health 2018:6:e1386-96.

52 Dimas J. CEPI awards funding agreement worth up to $\$ 9.5$ million to Colorado State University to develop a human vaccine against Rift Valley fever 2019

53 WHO. Efficacy trials of Rift Valley fever vaccines and therapeutics guidance on clinical trial design.

54 Busquets N, Xavier F, Martín-Folgar R, et al. Experimental infection of young adult European breed sheep with Rift Valley fever virus field isolates. Vector Borne Zoonotic Dis 2010;10:689-96. 
55 Garcia S, Crance JM, Billecocq A, et al. Quantitative real-time PCR detection of Rift Valley fever virus and its application to evaluation of antiviral compounds. J Clin Microbiol 2001;39:4456-61.

56 Liu J, Ochieng C, Wiersma S, et al. Development of a TaqMan array card for Acute-Febrile-Illness outbreak investigation and surveillance of emerging pathogens, including Ebola virus. J Clin Microbiol 2016;54:49-58.

57 Mwaengo D, Lorenzo G, Iglesias J, et al. Detection and identification of Rift Valley fever virus in mosquito vectors by quantitative real-time PCR. Virus Res 2012;169:137-43.

58 Sall AA, Macondo EA, Sène OK, et al. Use of reverse transcriptase PCR in early diagnosis of Rift Valley fever. Clinical and Vaccine Immunology 2002;9:713-5.
59 Sánchez-Seco M-P, Echevarría J-M, Hernández L, et al. Detection and identification of Toscana and other phleboviruses by RT-nestedPCR assays with degenerated primers. J Med Virol 2003;71:140-9.

60 Weidmann M, Sanchez-Seco MP, Sall AA, et al. Rapid detection of important human pathogenic Phleboviruses. J Clin Virol 2008;41:138-42.

61 Wilson WC, Romito M, Jasperson DC, et al. Development of a Rift Valley fever real-time RT-PCR assay that can detect all three genome segments. J Virol Methods 2013;193:426-31.

62 Wichgers Schreur PJ, Paweska JT, Kant J, Paul Schreur J. J, Schreur W, et al. A novel highly sensitive, rapid and safe Rift Valley fever virus neutralization test. J Virol Methods 2017;248:26-30.

63 Peyrefitte CN, Boubis L, Coudrier D, et al. Real-Time reversetranscription loop-mediated isothermal amplification for rapid detection of Rift Valley fever virus. J Clin Microbiol 2008;46:3653-9. 